\title{
ACRL actions, January 1988
}

\section{Highlights of the Midwinter meetings of the ACRL Board.}

$\mathbf{T}$ he Board of Directors of the Association of College and Research Libraries met twice during the ALA Midwinter Meeting in San Antonio, Texas: on Sunday, January 10, 1988, and Tuesday, January $12,1988$.

\section{Acid-free papers}

The Board endorsed a resolution submitted to ALA Council by the LAMA Governmental Affairs Committee on the "Use of Permanent Papers in Books and Other Publications." Two areas of concern were noted: clarification on a similar "Standard for Permanence," and the reasonableness of including the statement in "bibliographic references."

\section{Awards}

The Board confirmed its approval at Annual Conference of the Hugh C. Atkinson Memorial Award proposal and voted to donate $\$ 5,000$ to the award endowment.

\section{The Board}

The Board appointed Bob Carmack to complete the time remaining on Edward Jennerich's term (1988) as Director-at-Large. Carmack will serve on the ACRL Board until the close of the ALA 1988 Annual Conference in New Orleans.

\section{Books for College Libraries}

The Board dismissed the Books for College Libraries, Third Edition, Advisory Committee (ad hoc) with thanks for their work on the forthcoming publication.

\section{Chapters}

The Board accepted the petition for chapter status for the Western Pennsylvania area.

\section{Committee on Program Evaluation and Support (COPES)}

The Board voted to support a Spring 1988 meeting of ALA Division officers and COPES and agreed to share in the costs of the meeting.

\section{Consultants}

The Board directed the ACRL staff to explore the possibilities of cooperative projects that would produce directories of consultants in the areas of automation, community and junior colleges, and accreditation. The directories might be used to provide referrals to academic librarians in need of a consultant.

\section{Legislation}

The Board endorsed the Legislation Committee's resolution on academic library support for multi-type networking and the reauthorization of the Library Services and Construction Act. The resolution is found on pp.162-63 of this issue.

\section{Library theft guidelines}

The Board approved the "Guidelines Regarding Thefts in Libraries" developed by the RBMS Security Committee and referred them to the ALA Standards Committee for review. The guidelines appear on pp.159-62 of this issue.

\section{Non-tax sources of revenue}

The Board discussed a report by Anne Beaubien on a study of non-tax sources of revenue (fees, fines, fundraising, etc.) for public libraries and the possibility of conducting a similar study for academic libraries. Mel George and Anne Beaubien will prepare a proposal for the Board at Annual 


\section{Conference in New Orleans.}

\section{Output measures}

The Board voted to accept the proposal by Nancy Van House (UC-Berkeley School of Library and Information Studies) to write a manual for output measures for academic and research librarians. The manual will help to measure the quantity and quality of user services.

The $\$ 66,000$ cost of the manual will be spread over three years, with $\$ 22,000$ budgeted in FY 1988 from ACRL reserves and the remainder in FY 1989 and 1990. Funds from external agencies will be sought concurrently by the ACRL staff.

\section{Planning}

The Board approved the planning priorities timelines for 1988-89 and 1989-90, as presented by the Planning Committee. ACRL President-Elect Joe Boissé's priorities for 1989, "The Unfinished Agenda: Planning the Second Century," were endorsed as the Board's priorities (for a description, see p.141).

\section{Rare Books \& Manuscripts Librarianship}

The Board accepted the recommendation of the Publications Committee that the editor of $R B M L$ be appointed for a three-year term with a maximum of two reappointments. Additional policies and procedures for the RBML Editorial Board are under review by the Publications Committee.

\section{Sections}

The Board approved revisions to the CJCLS and CLS bylaws. See pp.163-65 for details.

The Board rescinded a fiscal policy (never put into effect) that a certain percentage of section membership funds be allocated to sections based on their membership.

\section{Special grant funds}

The Board approved the guidelines/criteria for special grant funds developed by the Special Grant Funds Committee, and agreed to budget $\$ 20,000$ as a separate budget line in 1989 for this fund. The guidelines appear on p.157 of this issue.

\section{Statistics}

The Board voted, at the request of the ACRL Academic Library Statistics Committee, to encourage the U.S. Department of Education's Center for Education Statistics to continue to gather and publish, in alternate years, statistics on academic libraries.

\section{ABC News, and Public Television bring their teams right into your library.}

Transcripts of today's most eventful TV journalism on microfiche, along with comprehensive indexes.

Quarterly delivery of current-year subscriptions, and complete backfiles available now from Research Publications.

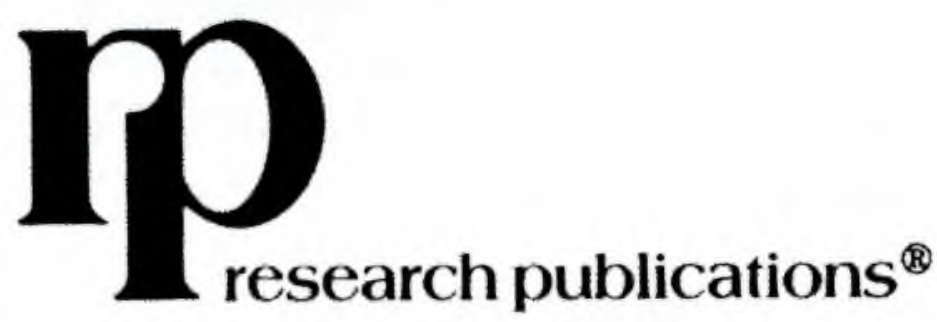

12 Lunar Drive/Drawer AB Woodbridge, CT 06525 1-800-REACH RP 